\title{
Consequentialism in Environmental Ethics
}

\section{Avram Hiller}

Forthcoming in The Oxford Handbook of Environmental Ethics, Stephen Gardiner and Allen Thompson, eds.

\section{(PENULTIMATE DRAFT - PLEASE CITE FINAL VERSION)}

What is valuable ${ }^{1}$ How should one act? There are numerous forms of consequentialism; what they have in common is that they answer the second question by appealing to an answer to the first. Consequentialists typically claim that an act is right when it produces the best state of affairs (relative to other acts the agent could have performed; Hooker, 2008), and then they offer a theory of what makes for the best state of affairs. For instance, classical act-utilitarianism, the most traditional form of consequentialism, holds that an act is right insofar as it maximizes overall utility, where utility is understood as the optimal balance of the most pleasure and least pain. Most consequentialists nowadays believe that the utilitarian focus on pleasure and pain is too simplistic, and thus provide alternative views of what makes for better or worse states of affairs.

A full explanation and defense of consequentialism in all its forms is well beyond the scope of this chapter (though see Sinnott-Armstrong, 2011; Driver, 2012), although along the way I shall say some things both in clarification of and in defense of consequentialism in general. My main focus will be on versions of consequentialism that pertain directly to environmental ethics. Although consequentialism has had a grand history as one of the principal types of ethical theory over the last 200 years or so, relatively few environmental ethicists have been consequentialists (Elliot, 2001: 181). Why this is the case is something I will not address here (but see Hiller and Kahn, 2014); instead, my goals are to discuss the contours of possible consequentialist environmental 
ethical views, compare environmental consequentialism with some competing environmental ethical views, and note challenges that a fleshed-out form of environmental consequentialism must meet. I will put special emphasis on examining a holistic environmental consequentialism, a view that has been, in my judgment, underdeveloped.

Two types of consequentialist accounts of our responsibilities with regard to the non-human world should be distinguished at the outset. First, a consequentialist may hold to a traditional anthropocentric view of value (see Thompson, chapter 6 of this volume) and argue that one must promote long-term human good, but to do so one must be concerned with how our actions affect the environment. Second, a consequentialist may adopt a theory of value according to which at least some non-human entities have intrinsic value. Although most forms of consequentialism explicated by philosophers who work primarily in environmental ethics are of this second kind, it will be instructive to begin by discussing a view of the first type, especially given its historical significance.

The end of the nineteenth century and the beginning of the 20th marked a turning point in United States environmental history in that the frontier, exploited over the first part of the country's history, was no longer seen as limitless. Gifford Pinchot, the first Head of the US Forest Service (beginning with the formation of the Forest Service under the Presidential administration of Theodore Roosevelt in 1905), was an avowed utilitarian (Pinchot, 1947; Nash, 1982; Katz, 1997), and Pinchot recognized that the greatest longterm benefit for people required conservation of natural resources. Pinchot thus helped fashion regulations that restricted exploitation of the natural environment. However, Pinchot was not and still is not universally hailed by environmentalists. Notoriously, 
Pinchot was instrumental in the decision to dam the Hetch Hetchy Valley in Yosemite National Park to provide drinking water for San Francisco. Pinchot testified before Congress in 1913:

I think that the men who assert that it is better to leave a piece of natural scenery in its natural condition have rather the better of the argument, and I believe that if we had nothing else to consider than the delight of the few men and women who would yearly go to Hetch Hetchy Valley, then it should be left in its natural condition. But the considerations on the other side of the question, to my mind, are simply overwhelming (Walsh et al., 2007).

Pinchot's reasons are entirely consequentialist and anthropocentric. On the other side of the debate, John Muir and the Sierra Club, which Muir founded, were adamantly opposed to the dam. ${ }^{2}$ The official position of the Sierra Club was given in a principle: "That our National Parks shall be held forever inviolate" (Colby, 1909). Muir wrote:

These temple destroyers, devotees of ravaging commercialism, seem to have a perfect contempt for Nature, and, instead of lifting their eyes to the God of the mountains, lift them to the Almighty Dollar. Dam Hetch Hetchy! As well dam for water-tanks the people's cathedrals and churches, for no holier temple has ever been consecrated by the heart of man (Walsh, et al. 2007). ${ }^{3}$

It is critical to recognize that there are two aspects of this critique of Pinchot's utilitarianism. The first is that what is held by Muir and the Sierra Club to be of value is more than just human good—Hetch Hetchy Valley itself has value. Second, certain acts 
of despoiling National Parks are always impermissible, regardless of the consequences of the acts. Importantly, it is possible to accept the first criticism of an anthropocentric utilitarianism without also accepting the second. Consequentialists may develop a theory of value according to which there are non-human goods, and claim that damming Hetch Hetchy is wrong because doing so does not maximize overall value. However, consequentialists will still bite the bullet in claiming that nothing should be held inviolate. For one can imagine circumstances in which a regulatory agency is faced with a choice of destroying one part of a National Park in order to save numerous parts from being destroyed in a like manner. Would it not be better, from the perspective of one who values nature, to commit the violation so as to maintain as much of the park as possible? ${ }^{4}$

This type of issue looms large in consequentialist theory. When G. E. M. Anscombe (1958) introduced the term "consequentialism," she intended it as a derogatory term. First, Anscombe argues that consequentialist views are wrong in that they to fail to distinguish between foreseeable consequences of an action from intended consequences. For Anscombe, it is appropriate to perform an act when the intended consequences are good even if the overall foreseeable consequences are not. In addition, Anscombe decries any view according to which certain acts that cause harm to innocent persons are morally right. Arguably, Anscombe is wrong on both counts (see Bennett, 1966 for an early response to Anscombe). If one intends to make a friend happy by buying him a statue made of ivory, it seems like a morally wrong act if one foresees that the purchase will lead to endangered elephants being killed. And one can imagine highly unfortunate scenarios in which harming an innocent person will end up saving numerous innocent persons from being harmed. Why do we intuitively hold that harming an 
innocent person is wrong? The reason, it seems, is that the outcome of doing so is that an innocent person will be harmed. But if one is so concerned about preventing innocent persons from being harmed, then it is seemingly irrational to approve of activities that lead to more such harm when one could act to minimize it. In short, whatever one takes to be of value - human life, human integrity, animal well-being, wilderness areas-it would be wrong to act in such a way that, ceteris paribus, more of what is of value is destroyed.

As I have noted, most consequentialist environmental ethicists accept that there are non-human goods, and in what follows I shall focus on the varieties of such nonanthropocentric views. A good place to begin is to note that Jeremy Bentham, founder of utilitarianism, argues that the welfare of nonhuman animals may be considered in moral calculus (Bentham [1789] 1996). This utilitarian view is elaborated upon in great detail by Peter Singer in his book Animal Liberation (1975) and elsewhere. Singer's view is sentientism — all and only sentient beings' experiences have value (see Gruen, Chapter 7 of this volume). Singer does argue that we should preserve natural areas and non-sentient things, but only on instrumental grounds; ecological habitats, and the non-sentient organisms in them, are necessary to support sentient animals in leading satisfying lives but are not valuable in themselves.

Arguably, Singer's sentientist consequentialist position in favor of animal welfare is more plausible than the main alternative - the rights-based approach of Tom Regan (1983). In Regan's view, animals with certain psychological attributes have rights, and this entails, for instance, that one should never conduct medical testing on animals even if it promotes the greater good. However, it seems reasonable, in some cases at least, that if 
the benefit of conducting testing on animals will be significant relative to the harm caused to a few animals, then it is permissible. A sentientist consequentialist approach, which tallies the good against the bad, will have this result.

One may object to sentientist consequentialism on the ground that it fails to properly respect the intrinsic values of non-sentient living things (see Palmer, Chapter 8 of this volume). Robin Attfield, in a series of works (Attfield, 1983, 1999, 2003, 2014), defends biocentric individualism, the idea that all and only living things have value. Although others such as Albert Schweitzer ([1923] 2008) and Paul Taylor (1986) defend the value of all living things, Attfield is unique in doing so from a consequentialist perspective. Like Schweitzer and Taylor, Attfield appeals to the fact that living things have interests and capacities in pursuing their own good, and this qualifies them as having value (Attfield, 1999: 39). However, unlike Schweitzer and Taylor, Attfield is an inegalitarian - he believes that although all and only living things are valuable, not all living things are equal in value. Some organisms have higher capacities, such as for autonomous action, and such creatures have greater value than organisms with more limited capacities. This helps biocentric individualism avoid the implausible consequence that a blade of grass is equally morally considerable to a chimpanzee or human.

Still, some philosophers, and certainly many environmentalists who are not professional philosophers, find even biocentrism to be too limited. Sentientist and biocentric consequentialism are in principle consistent with massive alteration of native ecosystems and even the extinction of many species for the purpose of maximizing positive sentient experience or maximizing the good of living things, respectively. (Some utilitarians, such as Brian Tomasik, 2014, embrace this ramification.) Instead, what 
matters, according to many, is the flourishing of ecosystems (see Callicott, Chapter 9 of this volume). However, unlike sentientist consequentialism, with its lengthy defense by Singer, and unlike biocentric consequentialism, with its well-developed account given by Attfield, there has not been an extensive and detailed explication or sustained defense of a fully consequentialist position that accepts ecosystemic values. I shall thus dedicate much of the remainder of this chapter to this kind of consequentialism, although the remarks I make will of necessity be a mere sketch of a position.

Famously, Aldo Leopold's "Land Ethic" is ecocentric, and it is phrased in what appears to be consequentialist terms ([1949] 1980, 262): "A thing is right when it tends to preserve the integrity, stability, and beauty of the biotic community. It is wrong when it tends otherwise.” However, James Fieser argues (1992)—successfully in my opinionthat Leopold did not intend the land ethic as a primary moral principle, let alone an actconsequentialist one. As Fieser claims, Leopold either was ignorant of utilitarianism or chose not to deeply engage with it (also see Moline, 1986). Of course, Leopold's views have been adopted by philosophers who are indeed well aware of normative theory. $\mathrm{J}$. Baird Callicott, for instance, accepts Leopold's Land Ethic and in his early work seems to accept some of its consequentialist implications (Callicott, 1989).

However, the charge of so-called "environmental fascism," as levied by Tom Regan (1983: 361), led Callicott to abandon consequentialism (Callicott, 1999: 172-173). Regan argues that accepting Leopold's Land Ethic as the single moral principle would absurdly entail that it is more morally appropriate to kill a human being rather than an endangered wildflower. Similar to what we saw in the case of the Sierra Club's criticism of Pinchot, the environmental fascism objection raises two distinct issues. As Clare 
Palmer notes (1998: 136), there is, first, the standard objection to consequentialism that it does not protect inviolable individual human rights, and second, there is an objection against the view that a wildflower, in its ecosystem, may contribute more to overall value than a human. I shall say more about environmental fascism below; for now I simply note that Callicott responds by disavowing his earlier acceptance of the Land Ethic as the single principle for right action. ${ }^{5}$

However, it is not hard to imagine an act-consequentialist view that upholds the spirit of Leopold's view and that can withstand the objection from environmental fascism. Elsewhere, I argue in favor of what I call system consequentialism (Hiller, 2014). Like other forms of maximizing act-consequentialism, it is the view that one should act so as to produce the best state of affairs. But it adds an important proviso: To determine what is the best state of affairs, one should not simply aggregate the goods that are possessed by individuals. Instead, the best state of affairs is the one that has the most systemic good. In what follows, I shall briefly explain the notion of systemic good and how it may fit within a consequentialist ethic, and I argue that a refined version of it does not succumb to the problem of environmental fascism.

A system may be defined as a whole with interdependent parts (Leopold, [1949] 1980: 262; Callicott, 1999: 130-131). There are many details that must be given in a full metaphysical account of interdependence, and I shall not attempt to give such an account here (though see Hiller, 2013). Still, ecosystems can be considered to be paradigm cases of systems. Organisms within an ecosystem have evolved with other organisms in the ecosystem, and thus members of the various species form an interdependent web. What makes an ecosystem valuable? Leopold's original characterization of ecosystemic 
goodness invokes a notion of stability, but most ecologically minded philosophers nowadays reject stability as an ecosystemic value. Because of this, it is difficult to arrive at an uncontroversial notion of ecosystemic value. Still, by defining ecosystemic health in a dynamic way, a number of philosophers still do attribute value to ecosystems (see especially McShane, 2004; also see Callicott, 1999 and Chapter 9 of this volume; Rolston, 1988, and 1991; Jamieson, 2002).

One feature of system consequentialism is that it may help explain, in consequentialist terms, what is (prima facie) wrong about cases where humans disrupt ecosystems. On a common view, disrupting an ecosystem is, in itself, a bad thing. For instance, Robert Elliot (1997) holds that when humans interfere in a natural system, the resultant area will have less value than an otherwise identical ecosystem that has not been disrupted by human action. But this type of anti-interference judgment seems at odds with consequentialism: typical consequentialists hold that what matters in the evaluation of an action is only the outcome of the action, and if two actions lead to states of affairs that are otherwise identical, then the actions should be judged equally. But if an impacted ecosystem is not as valuable as an otherwise identical one that humans have chosen not to disturb, it is hard to see how a consequentialist can account for the difference. Elliot, who himself otherwise is a supporter of a consequentialist environmental ethic, abandons consequentialism at this crucial juncture (Elliot, 1997: 113-114).

Despite initial appearances, this is not an intractable problem for the ecologically minded consequentialist. When a human acts, the act may be more or less in accord with systemic, ecological good, for some human actions are contrary to natural systems and others are not. On the assumption that we are able to make prior value judgments about 
the good of systems, in cases where a human action disrupts a natural system we can say that there is something about the very action itself that makes the state of affairs less valuable. This view also allows that human actions can contribute positively to overall value if they are done in accord with natural systems, in the same way that the action of any organism is good when it is done in accord with its natural ecosystem. But to be clear, this is merely to say that some human acts can be assessed as contributing to systemic good or bad, which is not the same as saying that such acts are, on their own, right or wrong. ${ }^{6}$ Thus an impacted ecosystem has less value than an otherwise identical, undisturbed one simply because systemic good is greater when a system that has historically not been inhabited by humans remains free from human interference. However, there remains the problem of environmental fascism. If we value ecosystems, and if preserving a single endangered wildflower maintains ecosystemic good more than saving a human, then it seems that we should value the flower more than the human. Yet ecosystems do not seem to be harmed when humans steal or commit murder (Fieser, 1992), but surely we should have an ethic that prohibits such actions in at least most situations.

As I just noted, there are two aspects to the charge of environmental fascism. I shall set aside further discussion of the issue of whether it is ever right to cause harm to one individual for the sake of the greater good, since that is a more general concern for consequentialists. Instead, I shall focus on the charge that system consequentialism may absurdly place more value on flowers than on humans (or other sentient organisms). The system consequentialist may first note that indeed a long-term reduction of the human population may be best, but this in itself would not justify murder, since there are much 
better ways of lowering population (such as providing increased education for women). Second, one may accept multidimensional consequentialism, a view developed by Alan Carter (2005). ${ }^{7}$ In Carter's view, there is a plurality of values—anthropocentric, zoocentric, biocentric, and ecocentric. According to Carter, there is no inconsistency in claiming that ecosystems are valuable but humans are as well, and human good can in some cases outweigh ecosystemic good. Carter specifically uses this to respond to the problem of environmental fascism (Carter, 2011b). For Carter, there is a plurality of goods that must be weighed against each other in determining right action.

However, there is a potential problem with Carter's view. According to Carter, the different kinds of value are independent of each other. But this seems mistaken, for arguably, ecocentric values are not independent of biocentric, zoocentric, or even anthropocentric values, given that ecosystems simply are composed of non-sentient living things, sentient animals, and in some cases humans (in addition to non-living things; see Attfield, 2014 for a similar concern). But this consideration allows for another form of response to the problem of environmental fascism. Although for the system consequentialist, the ultimate value is the value of systems, the value of a system may be taken to depend, in part, on what individuals are in the system. Ecosystems with more complex and sentient animals may be taken to be more valuable systems than functionally similar ones that have only non-sentient individuals. Thus if one were to choose to save a wildflower over a human or other sentient animal, the total value of the ecosystem would decrease even if its ecosystemic health increases. How far this modification of eco-consequentialism moves away from an original Leopoldian 
ecocentric vision and toward a more anthropocentric or sentientist one is a matter for investigation beyond the scope of this chapter. ${ }^{8}$

Having discussed various forms of environmental consequentialism, it may be instructive to compare environmental consequentialism with alternative forms of environmental ethical theory-deontology (see Hale, Chapter 17 of this volume), virtue theory (see Sandler, Chapter 18 of this volume), and pragmatism (see Minteer, Chapter 43 of this volume). Although there are stark differences between the views, there is also, perhaps surprisingly, quite a bit of common ground. I have already argued briefly that there are reasons to believe that there should be no inviolable deontological restrictions, and that what motivates deontological restrictions ought to be framed in consequentialist terms . However, maintaining that certain actions have negative axiological valence when they disturb ecosystems is a step toward deontology, and as I argue elsewhere, the system consequentialist can accept a wide range of intuitive judgments that typically are upheld by deontological views (see Hiller, 2014). Still, even though it holds that some acts have axiological valence, system consequentialism remains a consequentialist view in that it holds that whether an act is right can be determined only be appealing to the full range of states of affairs that ensue if one performs the act.

Both environmental virtue ethicists (see e.g., Hill Jr., 1983) and environmental pragmatists (see e.g., Norton, 2005) criticize the core notion for any consequentialist theory, the notion of intrinsic value. I will address the issue of intrinsic value momentarily, but I will briefly note at the outset that numerous defenses of claims of intrinsic value, which can be employed by consequentialists, have been made by philosophers writing on environmental ethics on both meta-ethically objectivist (Rolston, 
1988) and subjectivist (Callicott, 1999; Jamieson, 2008; McShane, 2007; McShane, 2011) grounds.

There is perhaps more in common between consequentialism and both environmental virtue ethics and environmental pragmatism than one might initially think. Although Robert Elliot argues on consequentialist grounds that a version of environmental virtue ethics problematically requires some prior notion of what is good in nature (Elliot, 1997: 55-58), there are other forms of environmental virtue ethics that are not susceptible to Elliot's argument. For instance, Ronald Sandler's Character and Environment (Sandler, 2007)—perhaps the most complete work dedicated to explicating and defending environmental virtue ethics - is in fact quite similar to a consequentialist view, for according to Sandler's view, what makes a character trait a virtue is that it is conducive to goodness (Sandler, 2007). As Sandler himself notes (Sandler, 2007: 32), his environmental virtue ethic is quite similar to rule-consequentialism. (However, see Thompson, 2008 for a criticism of Sandler from within environmental virtue ethics.) Furthermore, all consequentialists would encourage the development of virtuous character traits in promoting overall value.

The commonality between environmental pragmatism and environmental consequentialism may be first seen by noting how both views are outcome-oriented; consequentialist views simply formalize talk of good outcomes in a way that is grounded in axiological principles. In fact, some arguments used by environmental pragmatists straightforwardly support environmental consequentialism. For instance, consider Ben Minteer's analysis of Holmes Rolston's view regarding Nepalese tigers. Minteer writes: 
Because I subscribe to a contextual and experimental approach toward intrinsic value, I cannot follow Rolston and simply decide to 'put the tigers first' in Nepal... [For Rolston,] our obligations become immediately obvious - we must protect the park's biological integrity at any cost, including, perhaps, the lives of the distressed citizens at its borders. (Minteer, 2012: 70)

Minteer rejects this "at any cost" ethic. Setting aside whether this is the proper interpretation of Rolston's view, there is much here with which the environmental consequentialist will be sympathetic. Consequentialists will welcome the idea that judgments about how to act must be based upon the specific decision-making context and on empirical information about long-term consequences. And of course Minteer's rejection of the idea that one must save an animal species regardless of the consequences of doing so is the same kind of argument that consequentialists have long been leveling against deontologists, which I discussed previously.

In the end, environmental consequentialists and environmental pragmatists will part company about the nature of intrinsic value. Minteer's notion of the contextual nature of judgments of value is not the same as the consequentialist's. Minteer writes: “[N]oninstrumental claims [of value] are not epistemically or metaphysically foundational. They are contextual and are justified in terms of their ability to contribute to the resolution of specific environmental problems" (Minteer, 2012: 67). However, a consequentialist defender of intrinsic value would claim that by placing judgments of intrinsic value secondary to a logically prior notion of the "resolution" of environmental problems, environmental pragmatists put the cart before the horse. For what counts as a 
successful resolution? Certainly many environmental problems have been "resolved" by humans simply choosing to destroy the part of nature in question. But it seems that many such ways in which people have resolved problems are bad resolutions due to their negative impact on the natural world. But the pragmatist, who places judgments of intrinsic goodness and badness posterior to judgments about resolutions of problems, is in no position to make such a judgment. This issue is of course complex and deserves more attention than can be given here.

There is also a more general worry about intrinsic value that environmental pragmatists have expressed. They claim that a focus on the intrinsic value of the nonhuman world may be ineffective or even counterproductive in promoting environmental policy (see e.g., Light, 2005). However, a consequentialist environmental ethic is immune to this concern. First, consequentialists also want their theoretical views to be put into practice to have the best overall effects; but this may simply lead one to the view that what consequentialists say in academic texts should differ from what they say publicly when making policy arguments (see de Lazari-Radek and Singer, 2010). Second, the evidence is in fact quite strong that appeals to intrinsic value have had positive influence on people. For instance, Kempton et al. (1996) show that most people, even mill workers who lost their jobs due to use restrictions from the effort to preserve habitat for the spotted owl in the US Northwest, value the non-human world intrinsically. ${ }^{9}$

I have attempted to show that a form of consequentialism that accepts ecosystemic value but gives more value to humans and complex sentient animals is a promising view. Still, there are challenges that a fully fledged consequentialist environmental ethic faces. As I noted earlier, the system consequentialist needs to 
provide a theory of what a system is, what exactly makes systems good, and to what degree different systems are good. In fact, there has never been a consensus among consequentialists about the relative weights of any sets of values; ever since John Stuart Mill's criticism of simplistic hedonic utilitarianism (Mill, [1863] 1998) it has been a matter of controversy exactly how to measure good states of affairs. System consequentialism, which counts the complexity and sentience of the individual beings in an ecosystem as a source of increased value for the system, exponentially increases this difficulty. There is thus reason to believe that system consequentialists will never be able to provide a theory of the good that can help with real-world decision making.

I shall note two points in response to this worry. First, this is not on its own a fatal objection against system consequentialism or consequentialism more broadly. For a consequentialist may claim that it only demonstrates that in many cases, it is extremely difficult to determine what the right action or policy is. Uncertainty about what exactly is of value is not a sufficient reason to hold that we should abandon the project of giving a theory of what is valuable, for that would simply take us even farther away from knowing which actions are right. Second, some consequentialists have attempted to show that there are still rational ways to act even when there is uncertainty about the relative values between different kinds of goods—namely, by attributing weights to different views of value in a consequentialist calculus (Bykvist, 2014). If this view succeeds, uncertainty about levels of value should not lead us to reject consequentialism.

There are also concerns that due to the long-term and multidimensional nature of environmental problems, consequentialism will never be able to provide a decision procedure for actions or policies. ${ }^{10}$ However, a response similar to the previous one may 
be given. First, such a view simply shows that decisions regarding the environment are extremely difficult ones, and not that consequentialism is wrong. Second, we should still do our best to maximize expected utility, even if there is a great deal of uncertainty; to do anything else would be to act in a worse way.

Although there are still significant challenges for the development of consequentialist environmental ethics, it is in many respects a new field of inquiry, and there is hope that with further development it can be fleshed out more completely. My own view is that the fact that these outstanding questions exist should lead philosophers to work to resolve them on behalf of maximizing act-consequentialism rather than abandon it for its alternatives. For by abandoning maximizing consequentialism one will, by definition, fail to always endorse doing what has the most long-term good, whatever one takes to be good-be it human experiences, experiences of all sentient beings, ecosystems, or something else. Why should one ever prefer doing something other than what will lead to what is best?

\section{References}

Anscombe, G. E. M. (1958). “Modern Moral Philosophy.” Philosophy 33(124): 1-19.

Attfield, Robin (1991 [1983]). The Ethics of Environmental Concern, 2nd ed. Athens: University of Georgia Press.

Attfield, Robin (1999). The Ethics of the Global Environment. Edinburgh: Edinburgh University Press.

Attfield, Robin (2003) Environmental Ethics: An Overview for the 21st Century. Malden, MA: Blackwell. 
Attfield, Robin (2014). “Can Biocentric Consequentialism Meet Pluralist Challenges?” In Consequentialism and Environmental Ethics, edited by A. Hiller, R. Ilea, and L. Kahn. New York: Routledge.

Bennett, Jonathan (1966). "Whatever the Consequences." Analysis, 26(2): 83-102. Bentham, Jeremy (1996 [1789]). An Introduction to the Principles of Morals and Legislation, edited by J. Burns and H. L. A. Hart. Oxford: Clarendon Press. Bykvist, Krister (2014). "Evaluative Uncertainty, Environmental Ethics, and Consequentialism.” In Consequentialism and Environmental Ethics, edited by A. Hiller, R. Ilea, and L. Kahn. New York: Routledge.

Callicott, J. Baird (1989). In Defense of the Land Ethic: Essays in Environmental Philosophy. Albany, SUNY Press.

Callicott, J. Baird (1999). Beyond the Land Ethic: More Essays in Environmental Philosophy. Albany: SUNY Press.

Carter, Alan (2005). “Inegalitarian Biocentric Consequentialism, the Minimax Implication and Multidimensional Value Theory: A Brief Proposal for a New Direction in Environmental Ethics." Utilitas 17(1): 62-84.

Carter, Alan (2011a). "Some Grounding for a Multidimensional Axiology." Philosophical Studies 154: 389-408.

Carter, Alan (2011b). "Towards a Multidimensional, Environmentalist Ethic." Environmental Values 20(3): 347-374.

Crisp, Roger (2006). Reasons and the Good. New York: Oxford University Press.

De Lazari-Radek, Katarzyna, and Peter Singer (2010). "Secrecy in Consequentalism: A Defence of Esoteric Morality." Ratio 23: 34-58. 
Domsky, Darren (2006). "The Inadequacy of Callicott's Ecological Communitarianism.” Environmental Ethics 28: 395-412.

Driver, Julia (2012). Consequentialism. London: Routledge.

Elliot, Robert (2001). "Normative Ethics." A Companion to Environmental Philosophy, edited by Dale Jamieson, 177-191. Oxford: Blackwell.

Elliot, Robert (1997). Faking Nature: The Ethics of Environmental Restoration. London: Routledge.

Fieser, James (1992). "Leopold and The Compatibility of Eco-Centric Morality." International Journal of Applied Philosophy 7: 37-41.

Gardiner, Stephen (2011). A Perfect Moral Storm: The Ethical Tragedy of Climate Change. New York: Oxford University Press.

Hill, Jr., Thomas E. (1983). "Ideals of Human Excellence and Preserving Natural Environments." Environmental Ethics 5(3): 211-224.

Hiller, Avram (2013). “Object-Dependence.” Essays in Philosophy 14(1): 33-55.

Hiller, Avram (2014). “System Consequentialism.” In Consequentialism and Environmental Ethics, edited by A. Hiller, R. Ilea, and L. Kahn. New York: Routledge.

Hiller, Avram and Kahn, Leonard (2014). "Consequentialism and Environmental Ethics." In Consequentialism and Environmental Ethics, edited by A. Hiller, R. Ilea, and L. Kahn. New York: Routledge.

Holland, Alan (2014). "On Some Limitations of Consequentialism in the Sphere of Environmental Ethics." In Consequentialism and Environmental Ethics, edited by A. Hiller, R. Ilea, and L. Kahn. New York: Routledge. 
Hooker, Brad (2008). "Rule Consequentialism.” Stanford Encyclopedia of Philosophy. http://plato.stanford.edu/entries/consequentialism-rule// accessed June 10, 2013. Jamieson, Dale (2002). Morality's Progress: Essays on Humans, Other Animals, and the Rest of Nature. New York: Oxford University Press.

Jamieson, Dale (2008) Ethics and the Environment: An Introduction. Cambridge, England: Cambridge University Press.

Katz, Eric (1997). Nature as Subject: Human Obligation and Natural Community. New York: Rowman and Littlefield.

Kempton, Willet, Boster, James, and Hartley, Jennifer (1996). Environmental Values in American Culture. Cambridge, MA: MIT Press.

Lenman, James (2000). "Consequentialism and Cluelessness." Philosophy and Public Affairs 29(4): 342-370.

Leopold, Aldo (1980 [1949]). A Sand County Almanac, New York: Ballantine Books. Light, Andrew (2005). “What Is a Pragmatic Philosophy?” Journal of Philosophical Research 30 (Special Supplement) 341-356.

McShane, Katie (2004). “Ecosystem Health.” Environmental Ethics 26: 227-245.

McShane, Katie (2007). “Why Environmental Ethics Shouldn’t Give Up on Intrinsic Value." Environmental Ethics 29(1): 43-61.

McShane, Katie (2011). "Neosentimentalism and Environmental Ethics." Environmental Ethics 33(1): 5-23.

Mill, John Stuart (1998 [1863]). Utilitarianism, edited by Roger Crisp. Oxford: Oxford University Press. 
Minteer, Ben (2012). Refounding Environmental Ethics: Pragmatism, Principle, and Practice. Philadelphia: Temple University Press.

Moline, Jon (1986). “Aldo Leopold and the Moral Community.” Environmental Ethics 8(2): 99-120.

Moore, G.E. (1959 [1903]). Principia Ethica. Cambridge, UK: Cambridge University Press.

Nash, Roderick (1982 [1967]).Wilderness and the American Mind. 3rd ed. New Haven: Yale University Press.

Norton, Bryan G. (2005). Sustainability: A Philosophy of Adaptive Ecosystem Management. Chicago: University of Chicago Press.

Palmer, Clare (1998). Environmental Ethics and Process Thinking. Oxford: Clarendon Press.

Pinchot, Gifford (1998 [1947]). Breaking New Ground. Washington, DC: Island Press. Regan, Tom (1983). The Case for Animal Rights. Berkeley: University of California Press.

Rolston, Holmes (1988). Environmental Ethics. Philadelphia: Temple University Press. Rolston, Holmes (1991). "Environmental Ethics: Values in and Duties to the Natural World.” In The Broken Circle: Ecology, Economics, Ethics, edited by F. Herbert Bormann and Stephen R. Kellert, 65-84. New Haven, CT: Yale University Press. Sandler, Ronald (2007). Character and Environment: A Virtue-Oriented Approach to Environmental Ethics. New York: Columbia University Press.

Schweitzer, Albert (2008 [1923]). "Reverence for Life.” In Environmental Ethics, 5th ed., edited by Louis Pojman and Paul Pojman, 131-138. Belmont: Cengage. 
Sierra Club (1909). "1909 Letter to Gifford Pinchot."

http://www.sierraclub.org/ca/hetchhetchy/, accessed June 10, 2013.

Singer, Peter (1975). Animal Liberation. New York: Random House.

Sinnott-Armstrong, Walter (2011). “Consequentialism.” Stanford Encyclopedia of

Philosophy http://plato.stanford.edu/entries/consequentialism/ accessed June 10, 2013.

Taylor, Paul (1986). Respect for Nature, Princeton: Princeton University Press.

Thompson, Allen (2008). "Natural Goodness and Abandoning the Economy of Value."

Ethics, Place \& Environment, 11(2): 216-224.

Tomasik, Brian (2014). "The Importance of Wild Animal Suffering."

http://www.utilitarian-essays.com/suffering-nature.html, accessed April 4, 2014.

Walsh, Barry, Barnard, E., and Nesbitt, John (2007). "The Pinchot-Muir Split Revisited." http://www.safnet.org/fp/documents/pinchot_muri_split_07.pdf accessed June 10, 2013.

1 "Value," as used in this entry, denotes (except where noted) what is typically called "intrinsic value" rather than instrumental value. That is, value is what is good in itself as opposed to good for what a thing is used for.

${ }^{2}$ See Katz (1997, ch. 16) and Nash (1982, chs. 8, 10) for helpful discussion of the dispute between Muir and Pinchot.

${ }^{3}$ Muir,

http://www.sierraclub.org/john_muir_exhibit/writings/the_yosemite/chapter_16.a

spx, quoted in Walsh et al. (2007). 
${ }^{4}$ In defense of consequentialism, Robert Elliot (1997: 52 gives an example of setting fire to a certain natural area in order to create a firebreak to prevent a forest fire from spreading. Setting aside the issue of the naturalness of forest fires (many forest fires are indeed natural), in many situations it seems fully appropriate to create the firebreak even though doing so involves harming part of nature.

${ }^{5}$ Callicott ultimately describes his own view as a communitarian view and claims that there is a hierarchy of duties (seemingly echoing W. D. Ross) at different levels of community, and such duties preclude harming fellow humans (1989: 172-173). However, Callicott's communitarianism leaves him open to the objection (such as in Domsky, 2006) that his view entails the implausible claim that we owe no moral consideration to sentient beings who are not members of our community. Also see Carter (2005, appendix), for another critique of Callicott.

${ }^{6}$ As Crisp (2006: 41, fn. 7) notes, it is now common for consequentialists to claim that acts themselves have axiological valence. See also Hiller (2014).

${ }^{7}$ It should be noted that Carter (2005: 81), in the end, is not fully consequentialist.

${ }^{8}$ The view in this paragraph is perhaps an extension of G. E. Moore's principle of organic unities. On the one hand, Moore does not believe that the value of a unity is equal to the sum of the components. However, this still leaves open the possibility that the value of the whole is at least correlated with the values of the individuals in the whole. See Moore (1959/1903, ch. 1).

${ }^{9}$ Kempton et al. (1996, ch. 5). Although Light (2005: 345) cites Kempton et al. to support his claim that human attitudes toward nature are anthropocentric, the 
overall message from Kempton et al. is that in fact humans do value nature intrinsically.

${ }^{10}$ See Lenman (2000) for an elaboration of this issue. See Holland (2014) for an application of the problem to consequentialist environmental views. Also see Gardiner $(2011, \S 7.5)$ for a critique of utilitarian approaches that also applies to other forms of consequentialism, and ch. 8 for a critique of cost-benefit analysis. 